https://doi.org/10.30910/turkjans.744978

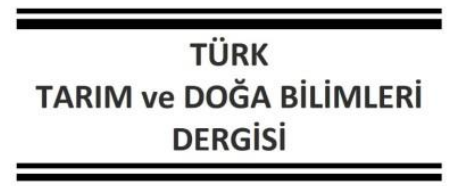

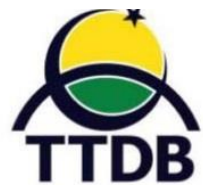

www.dergipark.gov.tr/turkjans

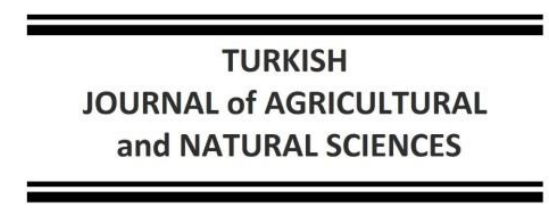

Araştırma Makalesi

\title{
Sakız Fasulyesi [Cyamopsis tetragonolaba (L.) Taub.]'nin Yaprak ve Tohum Ekstraktlarının Oksidatif DNA Hasarına Karşı Koruyucu Etkisi
}

\author{
Ceren SARAN ${ }^{1}$, Neslihan DEMIR ${ }^{2}$, Hanife GENÇ ${ }^{3 *}$
${ }^{1}$ Çanakkale Onsekiz Mart Üniversitesi, Lisansüstü Eğitim Enstitüsü, Tarımsal Biyoteknoloji Anabilim Dalı, Çanakkale, Türkiye
${ }^{2}$ Çanakkale Onsekiz Mart Üniversitesi, Fen Edebiyat Fakültesi, Biyoloji Bölümü, Çanakkale, Türkiye
${ }^{3}$ Çanakkale Onsekiz Mart Üniversitesi, Ziraat Fakültesi, Tarımsal Biyoteknoloji Bölümü, Çanakkale, Türkiye
*Sorumlu Yazar: hgenc@comu.edu.tr

\section{Geliş Tarihi: 29.05.2020 Düzeltme Geliş Tarihi: 09.10.2020 Kabul Tarihi: 14.10.2020}

\section{Öz}

Sakız fasulyesi [Cyamopsis tetragonolaba (L.) Taub.], yüksek sakız ve protein içeriğine sahiptir. Bu nedenle, geleneksel tıp alanında, kozmetik, ilaç endüstrisi, petrol endüstrisi, kâğıt, madencilik, tekstil sanayiinde ve gıda sektöründe kremşanti ve puding vb. gibi ürünlerde kıvam artıııcı olarak kullanılması yanında yem sanayisinde de kullanılan tek yıllık bir bitkidir. Bu çalışma, sakız fasulyesinin tohum ve yaprakların farklı konsantrasyonlarındaki $(1.56,3.125,6.25,12.5 \mu \mathrm{M})$ su ekstraktlarının agaroz jel elektroforez yöntemi ile pBR322 plazmid DNA üzerindeki hidrolitik ve oksidatif kırma aktivitelerinin incelenmesi amacıyla yapılmışır. Agaroz jel elektroforezinde, yaprak ekstraktlarının $6.25 \mu \mathrm{M}$ konsantrasyonda, tohum ekstraktında ise $6.25 \mu \mathrm{M}$ ve $12.5 \mu \mathrm{M}$ konsantrasyonlarında plasmid DNA'yı hidrolitik olarak kırdığı belirlenmiştir. Oksidatif kırma aktivitesi için oksitleyici ajan olarak $\mathrm{H}_{2} \mathrm{O}_{2}$ kullanılmıştır. Sakız fasulyesinin yaprak ekstraktının 6.25 ve 12.5 $\mu \mathrm{M}^{\prime}$ de, tohum ekstraktının $6.25 \mu \mathrm{M}^{\prime}$ de oksidatif olarak kırdığı $12.5 \mu \mathrm{M}^{\prime}$ de ise DNA'yı denatüre ettiği belirlenmiştir. Bu çalışma sonucunda sakız fasulyesinin hem yaprak hem de tohumunun sulu ekstraktlarında hidrolitik ve oksidatif DNA kırma aktivitesi tespit edilmiştir. Sakız fasulyesin kullanım alanları ve sıklğı dikkate alındığında antioksidan ve antimikrobiyal vb. aktiviteleriyle ilgili daha fazla çalışma yapılması gerekmektedir.

Anahtar kelimeler: Sakız fasulyesi, Cyamopsis tetragonolaba, Oksidatif DNA hasarı

\section{Protective Activity of Cluster bean's [Cyamopsis tetragonoloba (L.) Taub.] Leave and Seed Extracts Against Oxidative DNA Damage}

\begin{abstract}
The guar gum [Cyamopsis tetragonolaba (L.) Taub.] is an annual crop, has a high protein content and usually used for forage crop, traditional medicine, cosmetics, drug and petroleum industry, paper, mining, textile and food sectors, whipped cream and increased consistency. This study was carried out to investigate hydrolytic and oxidative cleavage activities with pBR322 plasmid DNA of different concentrations $(1.56,3.125$, $6.25,12.5 \mu \mathrm{M}$ ) of water extracts of gum beans seeds and leaves by agarose gel electrophoresis method. The plasmid DNA cleaved hydrolytically by leaf extracts at a concentration of $6.25 \mu \mathrm{M}$ and in seed extract at a concentration of $6.25 \mu \mathrm{M}$ and $12.5 \mu \mathrm{M}$ in agarose gel electrophoresis. $\mathrm{H}_{2} \mathrm{O}_{2}$ was used as the oxidizing agent for oxidative cleavage activity. As a result of this study, hydrolytic and oxitative DNA cleavage activity of guar gum were detected in both leaf and seed water extracts. When we consider the usage and frequency of guar gum, further investigations should be carried on antioxidant, and antimicrobial etc. activities.
\end{abstract}

Key words: Cluster bean, Cyamopsis tetragonolaba, Oxidative DNA Damage 


\section{Giriş}

Sakız fasulyesi [Cyamopsis tetragonolaba (L.) Taub.], baklagiller familyasına ait, kuraklığa dayanıklı olarak bilinen ve orijini Hindistan ve Pakistan olan tek yıllık bir bitkidir (Purseglove, 1981; Dougles, 2005; Batırca ve ark., 2017).

Guar gum olarak da bilinen sakız fasulyesi, yüksek protein içeriği ile yem bitkisi olarak sıkça tercih edilirken soya fasulyesinin yerini almaya aday bir bitkidir. Baklagiller familyasına ait bitkilerin genel özelliği olan yüksek azot içeriği ile toprak verimliliğini artırarak tarımsal anlamda da önemli olan sakız fasulyesi, kozmetik, ilaç, petrol endüstrisinde, kağıt, madencilik, tekstil sanayiinde ve gıda sektöründe de kremşanti ve puding gibi ürünlerde kıvam artırıcı olarak kullanılmaktadır (Undersander ve ark., 1991; Bewal ve ark., 2009; Batırca ve ark., 2017; Saeed ve ark., 2017).

Sakız fasulyesi, sindirim problemlerinin giderilmesinde müshil olarak geleneksel tıpta da sıklıkla kullanılır (Saeed ve ark., 2017). Dispepsi (hazımsızlık) ve anoreksiya (yeme bozukluğu) gibi rahatsızlıklar için kullanılmakla birlikte çok güçlü antisekretuar, hipolipidemik, anti-ülser, hipoglisemik, anti-hiperglisemik ve sitoprotektif etkilerinin bulunduğu bilinmektedir (Mukhtar ve ark., 2008; Saeed ve ark., 2017). Sakız fasulyesinin tohumlarının metanol ekstraktının farklı kanser hücre hatlarında antikanser aktivite gösterdikleri belirtilmiştir (Badr ve ark., 2014). Dünyada birçok ülkede farklı amaçlarla kullanılan sakız fasulyesi, ülkemizde ilk kez Çanakkale Onsekiz Mart Üniversitesi Ziraat Fakültesi tarafından yürütülen araştırmalarda kullanılmıştır (Batırca ve ark., 2017; Müftüoğlu ve ark., 2018; Akçura ve ark., 2019).

Reaktif oksijen türleri (ROS), serbest radikalleri ve biyolojik molekülleri okside edebilen radikal olmayan reaktif bileşikleri kapsamaktadır. Süperoksit, hidrojen peroksit, hidroksil radikalleri ve singlet oksijen aktif oksijen türlerinden sadece birkaçıdır. Oksidatif stress olarak tanımlanan ROS'un aşırı miktarda üretimi, DNA, protein, karbonhidrat ve lipitlerde hasarlara yol açabilmektedir (Piedrafita ve ark., 2015). Hücresel metabolitler ve eksojen ajanlar, genetik materyal olan DNA'nın yapısında, basit baz değişiklikleri veya bazın silinmesi, füzyon, translokasyon ve anöploidi gibi karmaşık değişiklikler ile DNA hasarına sebep olurlar (Sancar ve ark., 2004). Oluşan DNA hasarı, yaşlanma, kanser, mutasyon ve sonunda hücre ölümlerine sebep olabilir (Sancar ve ark., 2004; Rupp, 2006).

Hücreler bu stresin zararlı etkilerini önleyici ya da en az düzeye indirgeyici mekanizmalara sahip olmasına rağmen yapılan çalışmalarda nörodejeneratif hastalıklar, kardiyovasküler ve karaciğer hastalıkları, diyabet gibi ciddi hastalıklar, oksidatif strese bağlı DNA hasarıyla ilişkilendirilmiştir (Simic, 1988; Spector, 2000; Hancock ve ark., 2001; Tafani ve ark., 2016; Verma ve ark., 2018).

DNA kırma aktivitesine baktığımızda; hidrolitik yolla kırma işlemi, DNA'nın fosfodiester bağında meydana gelirken; oksidatif yolla kırma işlemi ise, şeker veya nükleobazlarda meydana gelmektedir. Çift sarmallı DNA molekülünün hidrolitik olarak kesimi, fosfodiester bağının hidrolizi ile sonuçlanmaktadır. Oksidatif olarak DNA kesimi, hidroksil radikali (HO·), süperoksit $\left(\mathrm{O}^{2-}\right)$ veya singlet oksijen (102) türleri gibi reaktif oksijen türlerinin (ROS) oluşmasıyla başlamaktadır. Bu serbest radikaller, şeker hidrojenlerini ayırarak DNA kesimini başlatmakta ve sonuçta DNA kesim ürünleri oluşmaktadır (Russo et al., 2001).

$\mathrm{Bu}$ çalışma kapsamında, sakız fasulyesinin yaprak ve tohumları kullanılarak elde edilen su ekstraktlarının farklı konsantrasyonlarda oksidatif DNA hasarı üzerine etkisinin belirlenmesi amaçlanmıştır.

\section{Materyal ve Metot}

\section{Materyal Temini ve Örneklerin Hazırlanması}

Çanakkale Onsekiz Mart Üniversitesi (ÇOMÜ) Ziraat Fakültesi Çiftliği Uygulama Alanında bulunan sakız fasulyesi deneme alanlarından toplanan bitkilerin ÇOMÜ Fen Edebiyat Fakültesi Moleküler Toksikoloji Laboratuvarı'nda yaprakları ve tohumları ayrılarak gölgede, devamlı hava akımı olan, serin bir ortamda kurutulmuştur (Şekil 1).

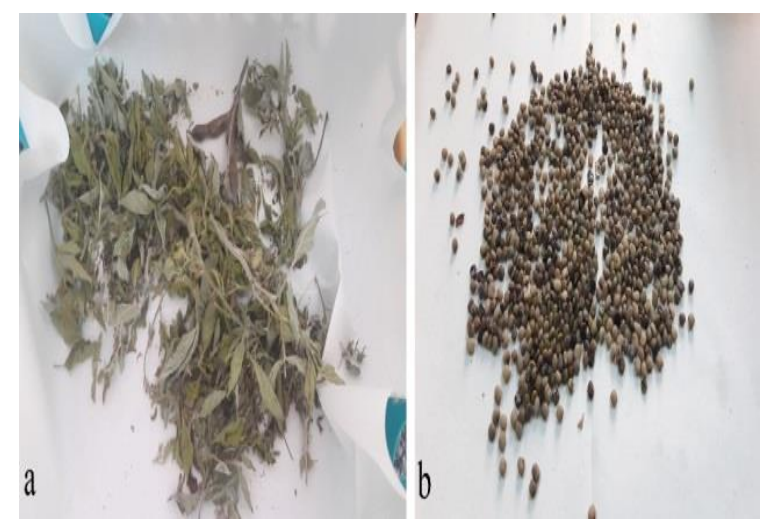

Şekil 1. Sakız fasulyesi bitkisinin kurutulması, yaprakları (a) ve tohumları (b)

Kurutulan yapraklar seramik havan ve tokmak yardımıyla, tohumlar ise değirmende öğütülüp toz haline getirilmiştir (Şekil 2). 


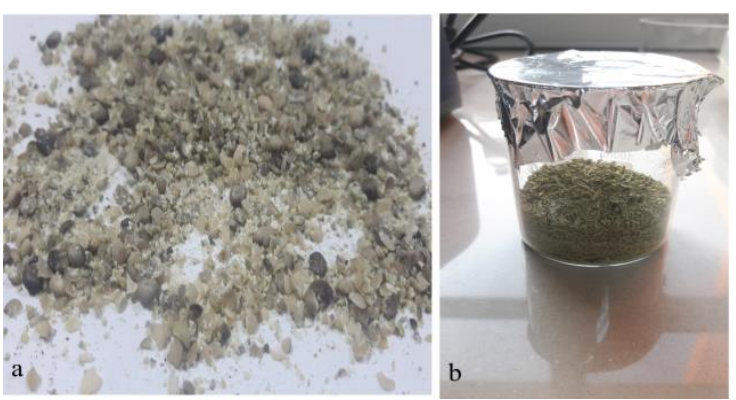

Şekil 2. Öğütülmüş sakız fasulyesi bitkisinin tohum (a) ve yapraklarının (b) görünümü

Her birinden $10 \mathrm{~g}$ tartılarak $100 \mathrm{~mL}$ distile su ile 24 saat soksilet cihazında (Wisd, Wise Therm) ekstraksiyon işlemi uygulanmıştır (Şekil 3).

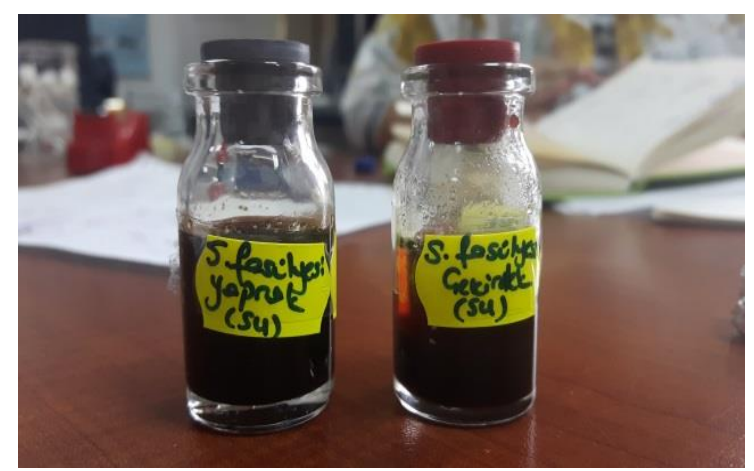

Şekil 3. Soksilet cihazında elde edilen sakız

fasulyesi yaprak ve tohumun su ekstraktları

Daha sonra, evaporatör (Spektral, Heidolph, Laborota 4001) yardımıyla su uçurulmuştur. Elde edilen ham ekstrakt buzdolabında +4 o C'de muhafaza edilmiştir.

\section{DNA Kırma ve Koruma Aktivitesi}

Çalışmada, hidrolitik ve oksidatif DNA kırma aktivitesi agaroz jel elektroforezi ile süpersarmal pBR322 plazmid DNA (Thermo Fisher Scientific) kullanılarak gerçekleştirilmiştir. Tris- $\mathrm{HCl}$ tamponundaki (10 mM, pH: 7.2) pBR322 DNA, 3 saat boyunca $37^{\circ} \mathrm{C}^{\prime}$ de inkübe edilmiştir. Oksidatif kırma mekanizmasını belirlemek için oksitleyici ajan olarak karışıma \% 3'lük Hidrojen peroksit $\left(\mathrm{H}_{2} \mathrm{O}_{2}\right)$ ilave edilmiştir. Inkübasyondan sonra $6 \mathrm{X}$ yükleme tamponundan (\% 0.25 bromofenol mavisi,\% 0.25 ksilen siyanol FF ve \% 30 gliserol) 4 $\mu \mathrm{L}$ eklenerek farklı konsantrasyondaki (1.56 $\mu \mathrm{M}$, $3.125 \mu \mathrm{M}, 6.25 \mu \mathrm{M}$ ve $12.5 \mu \mathrm{M})$ yaprak ve tohum örnekleri, TAE tamponu (40 mM Tris-asetat, $1 \mathrm{mM}$ EDTA, pH 8.2) içerisinde etidyum bromür içeren \% 1'lik agaroz jelde $60 \mathrm{~V}$ 'da 1 saat yürütülmüştür (Sabahi ve ark., 2018). Daha sonra, DNA bantları UV ışığı altında görüntülenerek fotoğraflanmıştır
(Quantum ST4 jel görüntüleme sistemi, Vilbar Lourmat).

\section{Bulgular ve Tartışma}

Plazmid DNA'nın süper sarmal yapısı olan Form I, DNA ipliklerinden birinde oluşan hasar ile açık dairesel bir forma dönüştüğünde Form II olarak adlandırılır. Her iki iplikteki hasar sonucunda oluşan lineer yapı ise Form I ve Form II arasında gözlemlenen Form III olarak bilinmektedir. Agaroz jel elektroforez sonucunda oluşan üç banttan biri olan Form I, Form II ve Form III'den daha hızlı hareket eder. Bu durum yük yoğunluğunun fazla ve hacminin az olmasından kaynaklanmaktadır (Mansour ve Ragap, 2019).

$\mathrm{Bu}$ çalışmada, sakız fasulyesinin yaprak ve tohumunun su ekstraktlarının farklı konsantrasyonlarının (1.56 $\mu \mathrm{M}, 3.125 \mu \mathrm{M}, 6.25$ $\mu \mathrm{M}, 12.5 \mu \mathrm{M})$ plasmid DNA üzerindeki kırma aktiviteleri incelenmiştir.

Sakız fasulyesi yaprak ekstraktının hidrolitik ve oksidatif kırma aktivitesi Şekil 4'de görülmektedir. Hidrolitik kırma aktivitesi incelendiğinde, yaprak ekstraktlarının $1.56 \mu \mathrm{M}$, $3.125 \mu \mathrm{M}$ ve $6.25 \mu \mathrm{M}$ konsantrasyonlarında DNA kırma aktivitesi göstermediği fakat $12.5 \mu \mathrm{M}$ konsantrasyonda tek zincir kırığı oluşturduğu (Form II) belirlendi (Şekil 4a). İyi bir oksitleyici ajan olan $\mathrm{H}_{2} \mathrm{O}_{2}$ varlığında, yüksek konsantrasyonlarda (6.25 $\mu \mathrm{M}$ ve $12.5 \mu \mathrm{M})$ oksidatif kırmaya sebep olduğu görülmüştür (Şekil 4b).

Sakız fasulyesi tohum ekstraktının hidrolitik ve oksidatif kırma aktivitesi Şekil 5' de gösterilmektedir. Tohumun su ekstrakları, düşük konsantrasyonlarda (1.56 $\mu \mathrm{M}$ ve $3.125 \mu \mathrm{M})$ hidrolitik kırma aktivitesine sahip değilken, uygulanan $6.25 \mu \mathrm{M}$ ve $12.5 \mu \mathrm{M}$ konsantrasyonlarda ise kırdığı tespit edilmiştir (Şekil 5a). Tohum ekstraktlarının $\mathrm{H}_{2} \mathrm{O}_{2}$ varlığındaki oksidatif kırma aktiviteleri incelendiğinde, $6.25 \quad \mu \mathrm{M}$ konsantrasyonunda DNA' da tek zincir kırı̆̆ı, 12.5 $\mu \mathrm{M}$ konsantrasyonda ise DNA'nın tamamını kırarak Form II ve Form III'e dönüştürmüştür (Şekil 5b).

$\mathrm{Bu}$ çalışma, sakız fasulyesi (Cyamopsis tetragonoloba) bitkisinin yaprak ve tohum su ekstraktlarının farklı konsantrasyonlarda (1.56 $\mu \mathrm{M}$, $3.125 \mu \mathrm{M}, 6.25 \mu \mathrm{M}$ ve $12.5 \mu \mathrm{M})$ oksitatif DNA hasarına karşı koruyucu etkisinin belirlenmesi amacıyla yapılmıştır. Yapılan çalışma ile sakız fasulyesinin tohum ve yaprak su ekstraktlarının artan konsantrasyonlarda DNA üzerinde kırılmaya yol açtığı tespit edilmiştir (Şekil 4 ve Şekil 5). 


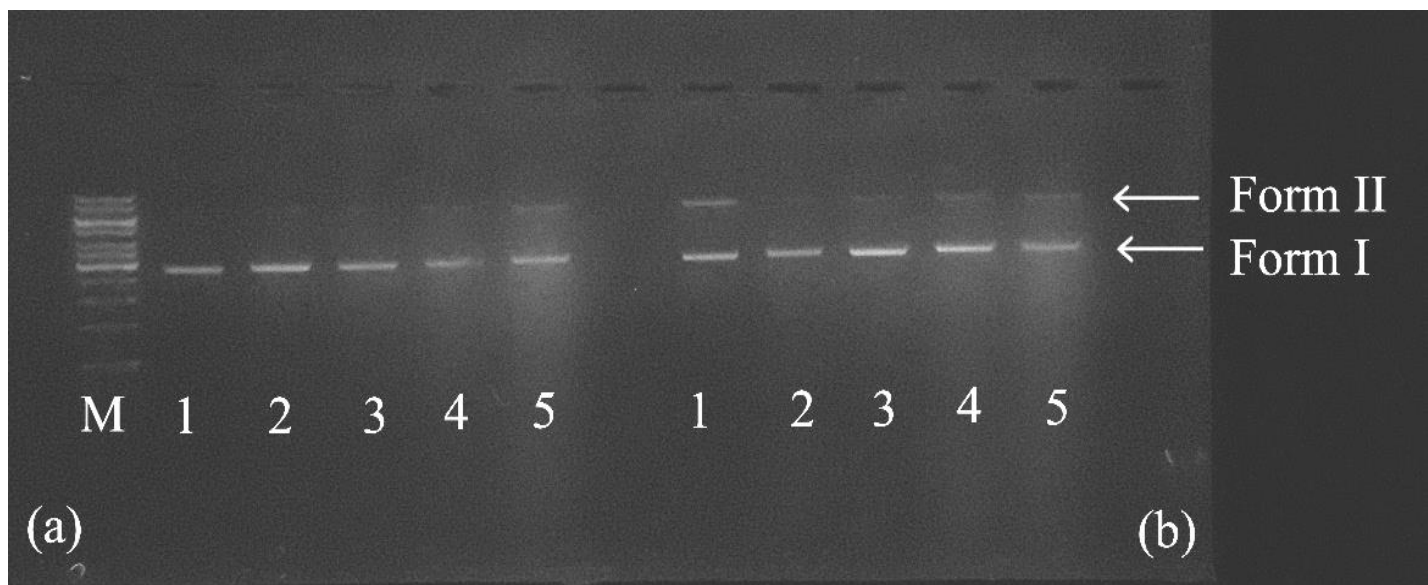

Şekil 4. Sakız fasulyesi yapraklarının su ekstraktının elektroforez görüntüsü. Marker (M), Hidrolitik (a); DNA (1), $1.56 \mu \mathrm{M}$ (2), $3.125 \mu \mathrm{M}(3), 6.25 \mu \mathrm{M}$ (4), $12.5 \mu \mathrm{M}$ (5). Oksidatif (b); DNA + $\mathrm{H}_{2} \mathrm{O}_{2}$ (1), $1.56 \mu \mathrm{M}$ (2), $3.125 \mu \mathrm{M}$ (3),6.25 $\mu \mathrm{M}(4), 12.5 \mu \mathrm{M}(5)$

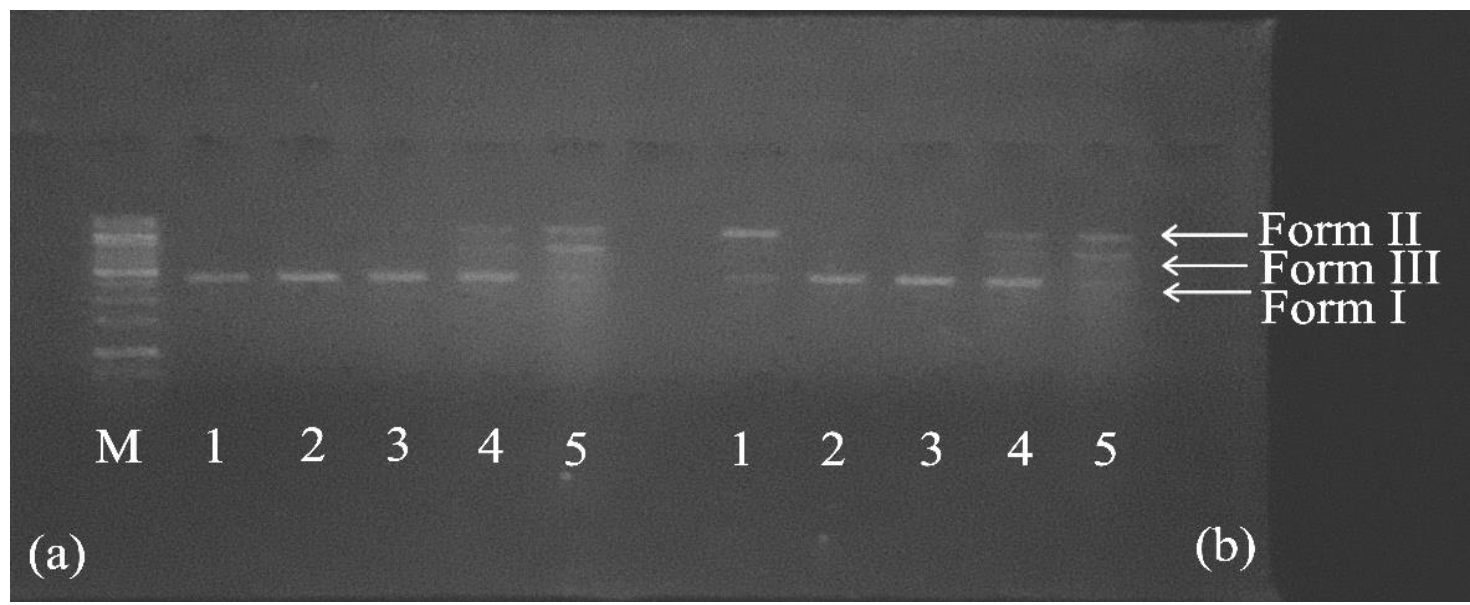

Şekil 5. Sakız fasulyesi tohum su ekstraktının elektroforez görüntüsü. Marker (M), Hidrolitik (a); DNA (1), 1.56 $\mu \mathrm{M}(2), 3.125 \mu \mathrm{M}$ (3), $6.25 \mu \mathrm{M}$ (4), $12.5 \mu \mathrm{M}$ (5). Oksidatif (b); DNA+ $\mathrm{H}_{2} \mathrm{O}_{2}$ (1), $1.56 \mu \mathrm{M}$ (2), $3.125 \mu \mathrm{M}$ (3), 6.25 $\mu \mathrm{M}(4), 12.5 \mu \mathrm{M}(5)$

Attaguile ve ark. (2000) yaptıkları çalışmada, Cistus incanus ve Cistus monspeliensis' in su ekstraktlarının DNA kırılması üzerindeki etkilerini ve serbest radikal temizleme aktiviteleri araştırmışlardır. Bu ekstraktların DNA kırılması üzerinde koruyucu bir etki ve doza bağlı serbest radikal temizleme kapasitesi gösterdiği yapılan çalışmada belirtilmiştir. Yapılan başka bir çalışmada Guha ve ark. (2009) çeşitli Hint kabileleri ve etnik gruplar tarafından kullanılan 14 tıbbi bitkiden, 56 ekstraktın (polar ve polar olmayan) oksidatif stresin sebep olan DNA hasarını önleme potansiyelini $\mathrm{H}_{2} \mathrm{O}_{2}$ varlığında pBR322 plazmid DNA incelemişler ve üç ekstraktın genotoksik aktivite gösterdiğini tespit etmişlerdir.

Buğdaygillerden tıbbi Desmostachya bipinnata bitkisinin DNA koruma aktivitesinin hem in vivo hem de in vitro olarak araştırıldığı bir çalışmada, $\mathrm{H}_{2} \mathrm{O}_{2}$ 'nin neden olduğu oksidatif hasarı bitkinin doza bağlı olarak önlediği sonucuna varılmıştır (Golla ve Bhimathai, 2014). Carissa carandas bitkisinin yapraklarından elde edilen metanol ekstraktının DNA hasarını inhibe etme potansiyelinin araştırıldığı bir başka çalışmada, bitkinin oksidatif DNA hasarına karşı doza bağlı olarak koruyucu etkiye sahip olduğu tespit edilmiştir. Ayrıca çalışmada C. carandas bitkisinin yüksek oranda fenolik madde içerdiği saptanmış olup, DNA koruma aktivitesinin de buna bağlı olarak gözlendiği belirtilmiştir (Verma ve ark., 2015).

Gul ve ark. (2017) Linaria corifolia bitkisinin toprak altı ve toprak üstü kısımlarının etanol (EtOH), etil asetat (EtOAc) ve diklorometan (DCM) ekstraktlarını antioksidan, antimikrobiyal ve DNA kırma özelliklerini açısından değerlendirmiştir. Aynı zamanda bazı fenolik bileşikler ve flavonoidler tanımlanarak bitkinin toprak üstü kısmından elde edilen ekstraktının içerdiği flavonoidlere bağlı 
olarak diğer ekstraktlara göre antioksidan özelliğinin daha yüksek olduğu tespit edilmiştir. Bitkiden elde edilen uçucu yağların biyolojik aktivitesi orta derecede olmasına rağmen, DNA'yı koruma özelliği diğer ekstraktlardan daha güçlü olduğu gözlemlenmiştir.

Fenolik maddeler, bitkilerde çok farklı fizyolojik görevleri yerine getiren ve en yaygın sekonder metabolitlerdir (Balasundram ve ark., 2006). Fenolik bileşiklerin DNA'yı dimerizasyon ve kırılmadan koruyarak hücre hasarına karşı bir koruma sağladığı düşünülmektedir (Strack, 1997). Çalışılan sakız fasulyesinde de fenolik bileşik miktarının yüksek olabileceği ve buna bağlı olarak da DNA koruma aktivitesine sahip olabileceği düşünülmektedir.

Sakız fasulyenin yaprak ve tohumlarının farklı konsantrasyonlardaki (1.56, 3.125, 6.25, 12.5 $\mu \mathrm{M})$ su ekstraktlarının DNA'yı doza bağlı olarak hidrolitik ve oksidatif olarak kırdığı bu çalışma ile ilk kez çalışılmıştır. $\mathrm{H}_{2} \mathrm{O}_{2}$ 'nin yol açtığı oksidatif hasara karşı düşük konsantrasyonlarının DNA üzerinde koruyucu etkisinin daha yüksek olduğu görülmüştür.

Sakız fasulyesi (Cyamopsis tetragonoloba) bitkisi geleneksel tıpta birçok hastalığın tedavisinde, yem bitkisi ve gıda maddesi olarak, ayrıca birçok sektörde sıklıkla kullanılan bir bitkidir. Sakız fasulyesi bitkisinin giderek artan önemi ve gıda sektöründeki payı dikkate alındığında bitkinin biyolojik aktiviteleri ile ilgili daha fazla çalışma yapılması gerekliliği ortya konmuştur.

Teşekkür: Çalışmada test edilen sakız fasulyesinin bitki ve tohumlarını temin eden Prof. Dr. Mevlüt AKÇURA'ya ve laboratuvar analizlerinde yardımcı olan Elif ÜNALDI 'ya teşekkür ederiz.

Çıkar Çatışması Beyanı: Makale yazarları aralarında herhangi bir çıkar çatışması olmadığını beyan ederler.

\section{Araştırmacıların Katkı Oranı Beyan Özeti:}

Yazarlar makaleye eşit oranda katkı sağlamış olduklarını beyan ederler.

\section{Kaynaklar}

Akcura, M., Turan, V., Kokten, K., Kaplan, M. 2019. Fatty acid and some micro element compositions of cluster bean (Cyamopsis tetragonoloba) genotype seeds growing under Mediterranean climate. Industrial Crops and Products, 128, 140-146.

Attaguile, G., Russo, A., Campisi, A., Savoca, F., Acquaviva, R., Ragusa, N., Vanella, A. 2000. Antioxidant activity and protective effect on
DNA cleavage of extracts from Cistus incanus L. and Cistus monspeliensis L. Cell Biology and Toxicology, 16: 83-90.

Badr, S. E. A, Abdelfattah, M. S., El-Sayed, S. H., Abd El-Aziz, A. S. E., Sakr, D. M. 2014. Evaluation of anticancer, antimycoplasmal activities and chemical composition of guar (Cyamopsis tetragonoloba) seeds extract. Research Journal of Pharmaceutical, Biological and Chemical Sciences,5(3): 413.

Balasundram, N., Sundram, K., Samman, S. 2006. Phenolic compounds in plants and agriindustrial by-products: Antioxidant activity, occurrence, and potential uses. Food Chemistry, 99: 191-203.

Batırca, M., Alatürk, F., Gökkuş, A. 2017. Gübrelemenin sakız fasulyesinin [Cyamopsis tetragonoloba (L.) Taub.] ot verimi ve bazı özelliklerine etkisi. Türk Tarım ve Doğa Bilimleri Dergisi, 4(1): 79-87.

Bewal, S., Purohit, J., Kumar, A., Khedasana, R., Rao, S.R. 2009. Cytogenetical investigations in colchicine-induced tetraploids of Cyamopsis tetragonoloba L. Czech Journal of Genetics and Plant Breeding, 45 (4): 143-154.

Dougles, C.A. 2005. Evaluation of guar cultivars in central and southern Queensland. Rural Industries Research and Development Corporation, 11s.

Golla, U, Bhimathati, S.S. 2014. Evaluation of antioxidant and DNA damage protection activity of the hydroalcoholic extract of Desmostachya bipinnata L. Stapf. Scientific World Journal, 2014:215084:8.

Guha, G., Rajkumar, V., Mathew, L., Kumar, R.A. 2009. The antioxidant and DNA protection potential of Indian tribal medicinal plants. Turkish Journal of Biology, 35: 233-242.

Gul, M., Ozturk Cali, I., Cansaran, A., Idil, O., Kulu, I., Celikoglu, U. 2017. Evaluation of phytochemical content, antioxidant, antimicrobial activity and DNA cleavage effect of endemic Linaria corifolia Desf.(Plantaginaceae). Cogent Chemistry, 3(1), 1337293.

Hancock, J.T., Desikan, R., Neill, S.J. 2001. Role of reactive oxygen species in cell signaling pathways. Biochemical Society Transactions, 29: 345-350.

Mansour, A.M., Ragap, M.S. 2019. Benzimidazol / 2,2'-bipiridin bazlı binükleer üçlü geçiş metali komplekslerinin DNA / lizozim bağlanma eğilimi ve nükleaz özellikleri. Royal Society of Chemistry, 9:30879-30887.

Mukhtar, H.M., Ansari, S.H., Bhat, Z.A, Naved T. 2008. Antihyperglycemic activity of 
Cyamopsis tetragonoloba. Beans on blood glucose levels in alloxan-induced diabetic rats. Pharmaceutical Biology, 44(1): 10-13.

Müftüoğlu, N.M., Türkmen, C., Akçura, M., Kaplan, M. 2018. Bazı yemeklik sakız fasulyesi (Cyamopsis tetragonoloba) genotiplerinin yeşil bakla verimleri ve yeşil bakla besin içeriklerinin belirlenmesi. Uluslararası Avrasya Doğal Beslenme ve Sağlıklı Yaşam Zirvesi, 12-15 Temmuz 2018, AnkaraTürkiye.

Piedrafita G, Keller MA, Ralser M. 2015. The impact of non-enzymatic reactions and enzyme promiscuity on cellular metabolism during (oxidative) stress conditions. Biomolecules; 5(3): 2101-2122.

Purseglove, J.W. 1981. Leguminosae. In Tropical Crops: Dicotyledons. Longman Group Ltd., Essex, U.K, s. 250-254.

Rupp, D.W. 2006. Molecular mechanism of DNA damage, October 2006, Web erişim: http://radonc.yale.edu/training/pdf/molecu lar_mechanisms.pdf Erişim Tarihi: 10 Mart 2008.

Russo, A., Izzo, A.A., Cardile, V., Borelli, F., Vanella A. 2001. Indian medicinal plants as antiradicals and DNA cleavage protectors. Phytomedicine, 8(2): 125-132.

Sabahi, Z., Soltani, F., Moein, M. 2018. Insight into DNA protection ability of medicinal herbs and potential mechanisms in hydrogen peroxide damages model. Asian Pacific Journal of Tropical Biomedicine, 8(2): 120129.

Saeed, M., Hassan, F. U., Shah, Q. A., Araın, M. A., El-Hack, M.E.A., Alagawany, M., Dhama, K. 2017. Practical application of guar (Cyamopsis tetragonoloba L. Taub) meal in poultry nutrition. Advances in Animal and Veterinary Sciences, 5(12): 491-499.

Sancar, A., Lindsey-Boltz, L.A., Ünsal-Kaçmaz, K., Linn, S. 2004. Molecular mechanisms of mammalian DNA repair and the DNA damage checkpoints. Annual Review of Biochemistry, 73:39-85.

Simic, M.G. 1988. Mechanisms of inhibition of freeradical processed in mutagenesis and carcinogenesis. Mutation Research, 202: 377-386.

Spector A. 2000. Review: oxidative stress and disease, Journal of Ocular Pharmacology and Therapeutics, 16:193-201.

Strack D. 1997. "Phenolic Metabolism," in Plant Biochemistry, P.M. Dev. \& J.B. Harborne (Eds.), London, UK, Academic Press, pp 387416.

Tafani, M., Sansone, L., Limana, F., Arcangeli, T., Santis, E.D., Polese, M., Fini, M., Russo, M.A. 2016. The interplay of reactive oxygen species, hypoxia, inflammation, and sirtuins in cancer initiation and progression. Oxidative Medicine and Cellular Longevity,2016: 3907147:18.

Undersander, D.J., Putnam, D.H., Kaminski, A.R., Kelling, K.A., Doll, J.D., Oplinger, E.S. and Gunsolus, J.L. 1991. Guar. In: Alternative Field Crop Manual. University of Wisconsin Cooperative Extension Service, University of Minnesota Extension Service, Center for Alternative Plant and Animal Products.

Verma, K., Divya Shrivastava \& Gaurav Kumar. 2015. Antioxidant activity and DNA damage inhibition in vitro by a methanolic extract of Carissa carandas (Apocynaceae) leaves. Journal of Taibah University for Science, 9(1): 34-40. 